\title{
Pharmacokinetics of flumequine and in vitro activity against bacterial pathogens of gilthead sea bream Sparus aurata
}

\author{
George Rigos ${ }^{1,3, *}$, Athanassios E. Tyrpenou ${ }^{2}$, Ioannis Nengas ${ }^{1}$, Maria Yiagnisis ${ }^{1}$, \\ Maria Koutsodimou ${ }^{1}$, Maria Alexis ${ }^{1}$, Gera M. Troisi ${ }^{3,4}$ \\ ${ }^{1}$ Laboratory of Fish Nutrition and Pathology, National Centre for Marine Research, Aghios Kosmas 16604, Ellinikon, Attiki, \\ Greece \\ ${ }^{2}$ Department of Residue Research, HPLC Laboratory, Institute of Veterinary Research of Athens, National Agricultural \\ Research Foundation, 25 Neapoleos Street, Agia Paraskevi 15310, Athens, Greece \\ ${ }^{3}$ School of Life Sciences, Kingston University, Kingston upon Thames KT1 2CC, Surrey, United Kingdom \\ ${ }^{4}$ Present address: Environmental Monitoring Unit, Department of Mechanical Engineering, Brunel University, \\ Uxbridge UB8 3PH, United Kingdom
}

\begin{abstract}
The present study investigated the kinetic profile of flumequine (FLU) in gilthead sea bream Sparus aurata $(170 \mathrm{~g})$ held at $19^{\circ} \mathrm{C}$ and evaluated its in vitro efficacy against important bacterial diseases in Mediterranean mariculture. Following a single intravascular injection $\left(10 \mathrm{mg} \mathrm{kg}^{-1}\right.$ fish), the distribution half-life $\left(t_{1 / 2 \alpha}\right)$ and the half-life of the terminal phase of elimination $\left(t_{1 / 2 \gamma}\right)$ of the drug were 0.2 and $30 \mathrm{~h}$ respectively. Tissue penetration of FLU was low, since both the apparent distribution volume of the drug at steady-state $\left(V_{d(s s)}\right)$ and the apparent volume of the central compartment $\left(V_{\mathrm{c}}\right)$ were small $\left(0.57\right.$ and $\left.0.15 \mathrm{l} \mathrm{kg}^{-1}\right)$. The mean residence time (MRT) was short (11 h) and the total clearance $\left(\mathrm{CL}_{\mathrm{T}}\right)$ of the drug was slow $\left(0.05 \mathrm{l} \mathrm{kg}^{-1} \mathrm{~h}^{-1}\right)$. Following oral administration $\left(20 \mathrm{mg} \mathrm{kg}^{1}\right)$, the bioavailability $(F \%)$ of FLU was $29 \%$ and the maximum plasma concentration was $1.7 \mu \mathrm{g} \mathrm{ml} \mathrm{m}^{-1}$. The minimum inhibitory concentration (MIC) of the drug in distilled water supplemented with $2 \%$ $\mathrm{NaCl}$ against Vibrio anguillarum Serotype 1b, Photobacterium damsela ssp. piscicida, V. alginolyticus, $V$. damsela and $V$. fluvialis was $0.15,0.3,1.2,0.019$ and $0.15 \mu \mathrm{g} \mathrm{ml}^{-1}$ respectively. The addition however of $10 \mathrm{mM} \mathrm{Ca}^{2+}$ and $55 \mathrm{mM} \mathrm{Mg}^{2+}$ to the medium resulted in an 8- to $>120$-fold reduction in FLU activity. The results indicate that FLU has an adequate kinetic profile in gilthead sea bream and that marine cations induce a significant impact on the activity of FLU, rendering its use against bacterial pathogens questionable.
\end{abstract}

KEY WORDS: Flumequine - Gilthead sea bream · Pharmacokinetics · Bioavailability · Minimum inhibitory concentration · Mediterranean mariculture

Resale or republication not permitted without written consent of the publisher

\section{INTRODUCTION}

Bacterial pathogens remain a considerable threat in fish farming, causing economic losses. Therefore, antibacterial drugs are of importance, particularly in diseases for which vaccines have not yet been developed. The continuous increase of fish farming worldwide has inevitably been accompanied by an extensive and occasionally improper use of antibacterial agents to confront these pathogens. This may have undesired consequences such as the emergence of bacterial

*Email: grigos@ncmr.gr pathogens resistant to the relative paucity of registered antibacterial agents. Consequently, the need for new agents with attractive chemotherapeutic properties in farmed fishes is of importance. Evaluation of the efficacy of an antibacterial agent is based on its activity against important bacterial pathogens, which is mainly calculated as the minimum inhibitory concentration (MIC) coupled with a measurement of its plasma levels in the target species. A fast kinetic profile of the candidate drug is desirable because treated fishes must be free from residues before marketing. 
The inclusion of such data would provide a complete picture of the clinical outcome, and possibly enhance the efficacy of the treatment and secure human health and the environment.

Flumequine (FLU) is a fluoroquinolone derivative which inhibits DNA-gyrase (Drlica \& Coughlin 1989). It is a broad-spectrum synthetic antibacterial agent mainly against Gram-negative bacteria. Previous studies have revealed that FLU induces satisfactory kinetic properties in some farmed fish species (Rogstad et al. 1993, Martinsen \& Horsberg 1995) and low MICs against important bacterial fish pathogens (Ledo et al. 1987, Martinsen et al. 1992), indicating that FLU is a promising therapeutic candidate for fish farming.

Ample information exists on the pharmacokinetics of FLU in coldwater fishes including the rainbow trout Oncorhynchus mykiss (Sohlberg et al. 1990, 1994), the European eel Anquilla anguilla (Boon et al. 1991, van der Heijden et al. 1994), the common carp Cyprinus carpio (van der Heijden et al. 1994), the Atlantic salmon Salmo salar (O'Grady et al. 1988, Rogstad et al. 1993, Elema et al. 1994, 1995, Martinsen \& Horsberg 1995), the Atlantic halibut Hippoglossus hippoglossus (Samuelsen \& Lunestad 1996, Samuelsen \& Ervik 1997, Hansen \& Horsberg 1999), the turbot Scophthalmus maximus (Hansen \& Horsberg 1999) and the channel catfish Ictalurus punctatus (Plakas et al. 2000).

A first attempt to determine the pharmacokinetics of FLU in warmwater-farmed fishes was performed on the sea bass Dicentrarchus labrax without including bioavailability data or MICs (Rigos et al. 2002). Additionally, the kinetic profile of FLU has previously revealed significant interspecific differences (van der Heijden et al. 1994), an indication that the extrapolation of treatment regimes and withdrawal times for target fishes using data derived from other species is improper and may result in false therapies and environmental pollution.

The aim of the present study was to provide additional information on the pharmacokinetic properties of FLU in the gilthead sea bream Sparus aurata, the main euryhaline farmed species, and to determine MICs against important bacterial pathogens of Mediterranean mariculture.

\section{MATERIALS AND METHODS}

Chemicals. FLU was obtained from Sigma Chemical. The chemicals used for processing the plasma samples (HPLC grade) were obtained from Labscan. Intravenous and oral doses of flumequine were dissolved in $0.1 \mathrm{M} \mathrm{NaOH}$ ( $\mathrm{pH}$ was adjusted to 10.5 with $\mathrm{HCl}$ ). During the experiments, fish were anaesthetised with quinaldine (Sigma Chemical).
Experimental design. Healthy gilthead sea bream Sparus aurata averaging $170 \mathrm{~g}$ were acclimatised for 2 wk prior to initiation of the study (facilities of the Laboratory of Fish Nutrition and Pathology, National Centre for Marine Research, Athens). The fish were maintained in cylindroconical fibreglass tanks (800 1) receiving $36 \%$ sea water at a temperature of $19 \pm$ $0.5^{\circ} \mathrm{C}$, and were starved for $2 \mathrm{~d}$ before the start of the experiment; they remained unfed during the study.

Intravascular injection. Prior to injection, the fish were anaesthetised $\left(2 \mathrm{ml} \mathrm{l}^{-1}\right)$ and weighed. They received $200 \mu \mathrm{l}$ of medicated solution at a dose of $10 \mathrm{mg} \mathrm{kg}^{-1}$ fish. To ensure the correct position of the needle (Microlance 23G $1_{1 / 4} 0.6 \times 30$, Becton Dickinson $\mathrm{SA}$ ) in the caudal vein, blood was aspirated into the syringe prior to and following injection. Fish that bled heavily were removed and replaced. Approximately 1 $\mathrm{ml}$ of blood was drawn from the caudal vein (some distance from the injection site) of several fish (4 to 5 individuals sampled once), at each of the time points following dosing $(0.5,1,4,8,16,24,48,70$ and $100 \mathrm{~h})$. Plasma was prepared from blood samples by centrifugation at $3500 \times g$ for $10 \mathrm{~min}$ at $4^{\circ} \mathrm{C}$. Plasma samples were stored at $-20^{\circ} \mathrm{C}$ until analysis.

Oral administration. Prior to oral administration of the drug, the fish were anaesthetised $\left(2 \mathrm{ml} \mathrm{l}^{-1}\right)$ and weighed. Previous experience with single drug administrations in their feed has shown considerable variation in the drug plasma concentration of treated fish; therefore FLU (20 $\mathrm{mg} \mathrm{kg}^{-1}$ fish) was administered via a stomach tube (diameter $2 \mathrm{~mm}$ ) in sterile aqueous suspensions $(0.4 \mathrm{ml})$ containing the red food stain erythrosine to detect eventual regurgitation of the drug. Fish which regurgitated the drug were excluded from the study. Approximately $1 \mathrm{ml}$ of blood was taken from the caudal vein of several fish (4 to 5 individuals) at each of the time points following dosing $(2,4,8,16,24,48,70$ and 100 h). Plasma preparation and storage conditions were identical to the protocol used for intravascular administration.

FLU analysis. The determination of FLU in plasma samples followed the methodology of a previous study (Rigos et al. 2002). Briefly, extraction of the drug in plasma samples $(200 \mu \mathrm{l})$ was conducted with $2 \mathrm{ml}$ ethyl acetate. Samples were vortexed and centrifuged at $5000 \times g$ before being evaporated with $\mathrm{N}_{2}$ at $50^{\circ} \mathrm{C}$. Resuspension of the drug was performed with $1 \mathrm{ml}$ of mobile phase (50\% acetonitrile:methanol [3+2] v:v, $50 \%$ trifluoroacetic acid $0.1 \%, \mathrm{pH} 2.15)$. The samples were filtered $(0.22 \mu \mathrm{m})$ before injecting $20 \mu \mathrm{l}$ thereof into the HPLC system (ALLIANCE $2690 \mathrm{MX}$, Waters $^{\mathrm{TM}}$ ) used for the detection of FLU, which consisted of a pump (Waters ${ }^{\mathrm{TM}}$ 510), an autosampler (Waters $^{\text {TM }} 717$ plus), a column (ZORBAX ${ }^{\alpha}$ SB-C18, $5 \mu \mathrm{m}[250 \times 4.6 \mathrm{~mm}])$ and a scanning fluorescence detector (Waters ${ }^{\mathrm{TM}}$ 474). The excitation wavelength 
was set at $327 \mathrm{~nm}$ and emission at $369 \mathrm{~nm}$. The flow rate was adjusted at $0.8 \mathrm{ml} \mathrm{min} \mathrm{m}^{-1}$ and the retention time was $7.5 \mathrm{~min}$. A standard curve for flumequine (10, 50,150 and $750 \mathrm{ng} \mathrm{ml}^{-1}$ ) in triplicate drug-free plasma samples was conducted $\left(\mathrm{r}^{2}=0.997\right)$. Oxolinic acid was used as internal standard. The percentage of recovery (75\%) was calculated by comparing FLU concentration in spiked plasma samples to a standard solution in $0.1 \mathrm{M} \mathrm{NaOH}$. The detection limit was $10 \mathrm{ng} \mathrm{ml}^{-1}$.

Pharmacokinetic analysis. The plasma data of the intravascular injection was analysed for best fit to a 2or 3-compartment open pharmacokinetic model by using non-linear regression analysis (NLREG 2001, PH Sherrod), following a semi-logarithmic plot of the data (curve EXPERT 1997, D Hyams) and least-square fitting (Ritschel 1986). The plasma data were better fitted to a 3-compartment open pharmacokinetic model (Fig. 1). The plasma concentration versus time curve was calculated from the 3-exponential equation:

$$
C=A \mathrm{e}^{-\alpha t}+B \mathrm{e}^{-\beta t}+\Gamma \mathrm{e}^{-\gamma t}
$$

where $C$ is the plasma concentration, $t$ is the time, $\alpha, \beta$ and $\gamma$ are the slopes of mono-exponential declining curves, and $A, B$ and $\Gamma$ are the zero time plasma concentrations. The diffusion processes were all assumed to follow first-order kinetics. Calculations of apparent volume of distribution at steady state $\left(V_{d(s s)}\right)$ and total body clearance $\left(\mathrm{CL}_{\mathrm{T}}\right)$ were performed in a model-independent way (Ritschel 1986). The area under the concentration-time curve (AUC) was calculated using the trapezoidal rule (Ritschel 1986) and was extrapolated to infinity. The half-lives were calculated from the equation $t_{1 / 2}=\ln 2 / \alpha, \beta$ or $\gamma$. The slope $\beta$ of the plasma data following oral administration used to extrapolate AUC to infinity was calculated from the last 4 time points of the elimination curve $\left(\mathrm{r}^{2}=0.98\right)$. Bioavailability $(F \%)$ was estimated according to the equation:

$F=\frac{(\text { AUC oral administration }) \times(\text { dose intravascular injection }) \times 100}{(\text { AUC intravascular injection }) \times(\text { dose oral administration })}$

MIC determinations. MICs were determined by the broth microdilution method at $22^{\circ} \mathrm{C}$. An antibiotic solution was made by dissolving FLU in distilled water along with $1 \mathrm{M} \mathrm{NaOH}$. Dilutions were made in Mueller Hinton broth (MHB) dissolved in either distilled water supplemented with $2 \% \mathrm{NaCl}$ or with $10 \mathrm{mM} \mathrm{Ca}^{2+}$ and $55 \mathrm{mM} \mathrm{Mg}^{2+}$ (which approximates Mediterranean salinity), since previous studies have stressed the impact of these cations on the activity of drugs in the marine environment (Barnes et al. 1995, Pursell et al. 1995). FLU concentrations in the test wells ranged from 0.019 to $38.25 \mu \mathrm{g} \mathrm{m}{ }^{-1}$.

The bacteria which inflict the most significant losses in euryhaline mariculture, comprising the primary pathogens Vibrio anguillarum Serotype $1 \mathrm{~b}$ and Photobacterium damsela ssp. piscicida, and the opportunistic bacteria $V$. alginolyticus, $V$. damsela and $V$. fluvialis, were acquired from the Fish Pathology Laboratory of the National Centre for Marine Research, Greece. All bacterial pathogens were derived from diseased farmed gilthead sea bream and sea bass from 2000 to 2001. Since, in Greek mariculture, disease cases related to these bacteria deal mainly with 1 isolate of each species (90\% frequency), only 1 representative strain (see Table 3) of each bacterial pathogen was tested. The Vibrio species and P. damsela ssp. piscicida

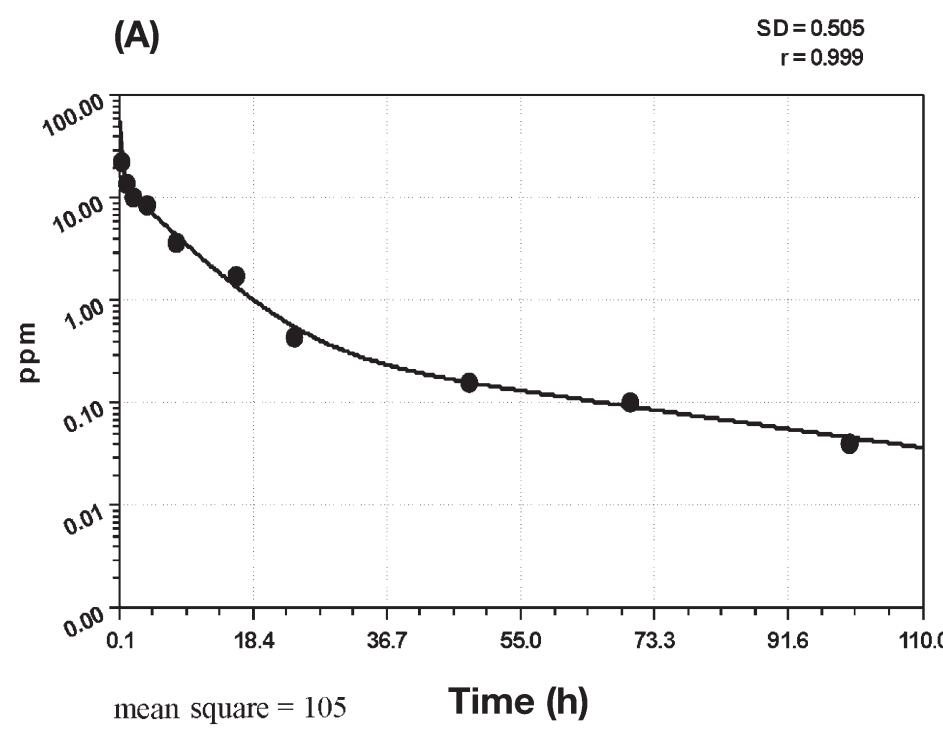

(B)

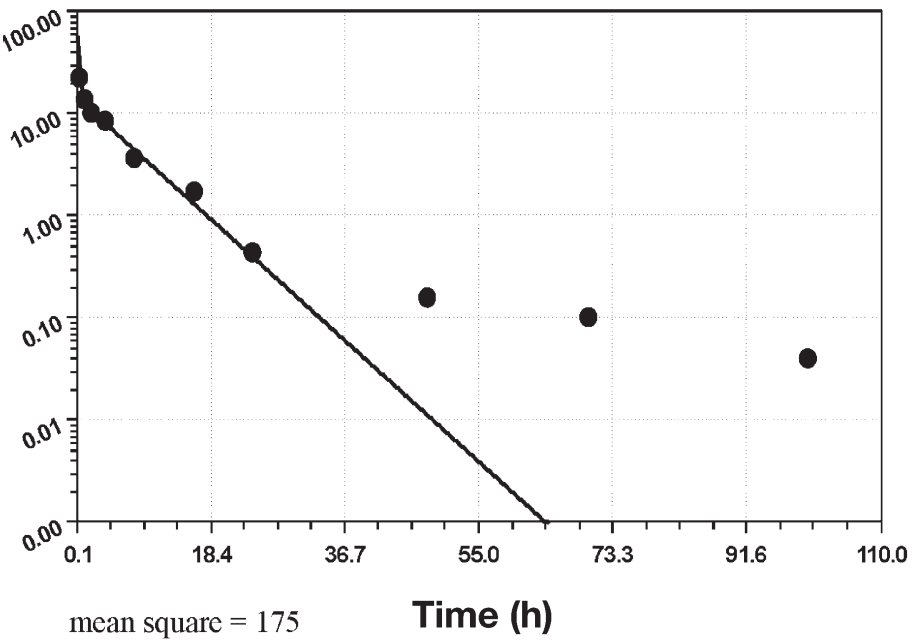

Fig. 1. Sparus aurata. Semi-log plot of flumequine plasma concentration vs time following injection against (A) a 3- or (B) a 2-compartment open pharma cokinetic model 
Table 1. Sparus aurata. Plasma concentration $\left(\mu \mathrm{g} \mathrm{ml} \mathrm{m}^{-1}\right)$ of flumequine (FLU) (mean \pm SD) following a single intravascular injection (10 $\mathrm{mg} \mathrm{kg}^{-1}$ fish) or oral administration (20 mg $\mathrm{kg}^{-1}$ fish) to gilthead sea bream $(170 \mathrm{~g} ; \mathrm{n}=4$ to 5$)$ held at $19^{\circ} \mathrm{C}$. Time points: hours post-administration

\begin{tabular}{|lrc|}
\hline Time points & Intravascular & Oral \\
\hline 0.5 & $22.71 \pm 4.92$ & \\
1 & $14.09 \pm 2.25$ & \\
2 & $10.36 \pm 1.25$ & $0.24 \pm 0.06$ \\
4 & $8.45 \pm 2.53$ & $0.28 \pm 0.03$ \\
8 & $3.64 \pm 1.45$ & $1.02 \pm 0.22$ \\
16 & $1.72 \pm 0.21$ & $1.73 \pm 0.34$ \\
24 & $0.43 \pm 0.20$ & $0.80 \pm 0.06$ \\
48 & $0.16 \pm 0.09$ & $0.50 \pm 0.01$ \\
70 & $0.10 \pm 0.02$ & $0.34 \pm 0.02$ \\
100 & $0.04 \pm 0.01$ & $0.12 \pm 0.02$ \\
& & \\
\hline
\end{tabular}

were identified according to Mercedes \& Blanch (1994) and Bakopoulos et al. (1995), respectively. Bacterial aliquots were taken from glycerol stocks and maintained on tryptic soya agar (TSA) supplemented with $2 \% \mathrm{NaCl}$. Single colonies were obtained from pure cultures (third passage on TSA), transferred to $10 \mathrm{ml}$ tryptic soya broth (TSB) and incubated aerobically for 24 to $48 \mathrm{~h}$ at $22^{\circ} \mathrm{C}$ to a final cell density of approximately $10^{6}$ cells $\mathrm{ml}^{-1}$ before being transferred to microtiter tray wells. Sterile tissue-culture plates (96well, flat bottom) with lids were used. To each well, we added $50 \mu \mathrm{l} \mathrm{MHB}, 50 \mu \mathrm{l}$ antibiotic solution and $10 \mu \mathrm{l}$ of each bacterial culture $\left(10^{4}\right.$ cells ml $\left.{ }^{-1}\right)$ with a multipoint

Table 2. Sparus aurata. Calculated pharmacokinetic parameters of FLU intravascularly injected ( $10 \mathrm{mg} \mathrm{kg}^{-1}$ fish) or orally administered (20 mg kg${ }^{-1}$ fish) into gilthead sea bream (170 g) at $19^{\circ} \mathrm{C} . \alpha, \beta, \gamma$ : slopes of monoexponential declining curves; $t_{1 / 2 \alpha}$ : distribution half-life of the drug; $t_{1 / 2 \beta, \gamma}$ : half-lives of the intermediate phase and the terminal elimination of the drug, respectively; $V_{d(s)}$ : apparent volume of distribution of the drug at steady-state; $V_{\mathrm{c}}$ : apparent volume of the central compartment; $\mathrm{CL}_{\mathrm{T}}$ : total body clearance of the drug; $\mathrm{AUC}_{0 \rightarrow \infty}$ : area under the drug concentration curve extrapolated to infinity; MRT: mean residence time; F: bioavailability

\begin{tabular}{|c|c|c|}
\hline Parameter & Intravascular & Oral \\
\hline$\alpha(\mathrm{h})$ & 3.47 & \\
\hline$\beta(\mathrm{h})$ & 0.16 & \\
\hline$\gamma(\mathrm{h})$ & 0.023 & \\
\hline$t_{1 / 2 \alpha}(\mathrm{h})$ & 0.2 & \\
\hline$t_{1 / 2 \beta}(\mathrm{h})$ & 4 & \\
\hline$t_{1 / 2 \gamma}(\mathrm{h})$ & 30 & \\
\hline$V_{d(s s)}\left(1 \mathrm{~kg}^{-1}\right)$ & 0.57 & \\
\hline$V_{\mathrm{c}}\left(1 \mathrm{~kg}^{-1}\right)$ & 0.15 & \\
\hline AUC $_{0 \rightarrow \infty}\left(\mu \mathrm{g} \mathrm{h}^{-1} \mathrm{ml}^{-1}\right)$ & 119.59 & 70.10 \\
\hline $\mathrm{CL}_{\mathrm{T}}\left(\mathrm{l} \mathrm{kg}^{-1} \mathrm{~h}^{-1}\right)$ & 0.05 & \\
\hline MRT (h) & 11 & \\
\hline$F(\%)$ & & 29 \\
\hline
\end{tabular}

pipette (Eppendorf). Plates were incubated for $48 \mathrm{~h}$ at $22^{\circ} \mathrm{C}$. Using a microplate reader (ASYS Hitech), each MIC was defined as the lowest drug concentration that inhibited bacterial growth. MIC testing was performed in triplicate. Individual MICs are the means of replicate results performed twice within a $1 \mathrm{wk}$ period.

\section{RESULTS}

\section{Pharmacokinetics}

The plasma levels of FLU from both routes of administration are presented in Table 1; the calculated pharmacokinetic parameters in Table 2. The distribution half-life $\left(t_{1 / 2 \alpha}\right)$ and the half-lives of the intermediate phase $\left(t_{1 / 2 \beta}\right)$ and the terminal phase of elimination $\left(t_{1 / 2 \gamma}\right)$ were calculated to be $0.2,4$ and $30 \mathrm{~h}$, respectively. The apparent distribution volume of the drug at steadystate $\left(V_{d(s s)}\right)$ and the apparent volume of the central compartment $\left(V_{\mathrm{c}}\right)$ were calculated to be 0.57 and $0.15 \mathrm{l}$ $\mathrm{kg}^{-1}$, respectively. The mean residence time (MRT) was estimated to be $11 \mathrm{~h}$ and the clearance of the drug $\left(\mathrm{CL}_{\mathrm{T}}\right)$ was calculated to be $0.05 \mathrm{l} \mathrm{kg}^{-1} \mathrm{~h}^{-1}$. The bioavailability $(F \%)$ of FLU was $29 \%$. The maximum plasma concentration following oral administration was $1.73 \mu \mathrm{g} \mathrm{ml}^{-1}$ measured $16 \mathrm{~h}$ post-administration. No peaks indicating metabolites of FLU in the plasma were observed.

\section{MICs}

The MICs of the drug using distilled water supplemented with $2 \% \mathrm{NaCl}$ against Vibrio anguillarum Serotype 1b, Photobacterium damsela ssp. piscicida, $V$. alginolyticus, $V$. damsela and $V$. fluvialis were 0.15 , $0.3,1.2,0.019$ and $0.15 \mu \mathrm{g} \mathrm{ml}^{-1}$, respectively; however, the addition of $10 \mathrm{mM} \mathrm{Ca}^{2+}$ and $55 \mathrm{mM} \mathrm{Mg}^{2+}$ to the medium resulted in MICs of $4.78,>38.25,38.25,0.15$ and $4.78 \mu \mathrm{g} \mathrm{ml}^{-1}$, respectively (Table 3 ).

Table 3. Minimum inhibitory concentrations (MICs) $\left(\mu \mathrm{g} \mathrm{ml}^{-1}\right.$ ) of FLU using either distilled water with added $2 \% \mathrm{NaCl}$ or additionally supplemented with $10 \mathrm{mM} \mathrm{Ca}^{2+}$ and $55 \mathrm{mM} \mathrm{Mg}^{2+}$ against important bacterial pathogens in Mediterranean mariculture at $22^{\circ} \mathrm{C}$. API: Analytical Profile Index

\begin{tabular}{|lccr|}
\hline $\begin{array}{l}\text { Bacterial } \\
\text { pathogens }\end{array}$ & API 20E & \multicolumn{2}{c|}{ MIC values } \\
& value & $2 \% \mathrm{NaCl}$ & + cations \\
\hline $\begin{array}{l}\text { Vibrio anguillarum 1b } \\
\text { Photobacterium }\end{array}$ & 3247524 & 0.15 & 4.78 \\
$\begin{array}{l}\text { damsela ssp. piscicida } \\
\text { V. alginolyticus }\end{array}$ & 4247525 & 1.2 & 38.25 \\
V. damsela & 2015004 & 0.019 & 0.15 \\
V. fluvialis & 3247127 & 0.15 & 4.78 \\
\hline
\end{tabular}




\section{DISCUSSION}

The present study evaluates FLU as a treatment agent in Mediterranean mariculture, investigates its pharmacokinetics in the main species reared in euryhaline fish farming (the gilthead sea bream Sparus aurata) and determines the MIC against important bacterial pathogens involved in this mariculture industry.

The distribution half-life $\left(t_{1 / 2 \alpha}\right)$ of FLU following intravascular injection into gilthead sea bream $(0.2 \mathrm{~h})$ indicates rapid distribution from the blood to the tissue compartments of the fish. Longer $t_{1 / 2 \alpha}$ of the drug have been estimated for the sea bass Dicentrarchus labrax (1.05 h: Rigos et al. 2002).

The bioavailability $(F \%)$ of FLU following oral administration to gilthead sea bream was relatively low $(29 \%)$, but close to the values reported for other farmed fishes. The $F$ of FLU has been calculated to be $44 \%$ in channel catfish (Plakas et al. 2000) and in the range of 31 to $59 \%$ in coldwater fishes (Rogstad et al. 1993, Elema et al. 1995, Martinsen \& Horsberg 1995, Samuelsen \& Ervik 1997, Hansen \& Horsberg 1999).

First-pass effect and malabsorption were previously suggested as factors limiting FLU bioavailability in freshwater fishes (Elema et al. 1995). FLU is a weak acid and, consequently, its absorption may be reduced by the unfavourable alkaline intestinal environment of marine fish. The possible complexing of FLU with cations such as $\mathrm{Ca}^{2+}$ and $\mathrm{Mg}^{2+}$ in the feed and in the marine environment could also partially explain the low F in marine fishes (Samuelsen \& Ervik 1997). Thus, a further reduction in bioavailability is likely to occur during at-site administrations of FLU through the diet, since the drug is given to gilthead sea bream in aqueous suspension.

The half-life of the terminal phase of elimination $\left(t_{1 / 2 \gamma}\right)$ of FLU in gilthead sea bream (30 h) was slower than that reported for other farmed fishes kept at high water temperatures. The elimination half-life of FLU was reported to be $10 \mathrm{~h}$ in sea bass kept at $18^{\circ} \mathrm{C}$ (Rigos et al. 2002) and $22 \mathrm{~h}$ in channel catfish maintained at $24^{\circ} \mathrm{C}$ (Plakas et al. 2000). The inter-specific differences observed in the elimination of FLU can be due to the fact that in fishes, as in mammals, species-dependent differences exist in the liver microsomal cytochrome P450-dependent mixed-function oxidase system which is the primary mechanism in catalysing the oxidative metabolism of a variety of drugs, together with other exogenous compounds (Stegeman 1989).

The apparent distribution volume of the drug at steady-state in gilthead sea bream $\left(V_{d(s s)}=0.57 \mathrm{l} \mathrm{kg}^{-1}\right)$ is similar to that in channel catfish $\left(0.527 \mathrm{~kg}^{-1}\right)$ (Plakas et al. 2000), but smaller than in sea bass $\left(1.51 \mathrm{l} \mathrm{kg}^{-1}\right.$ : Rigos et al. 2002). The apparent volume of the central compartment $\left(V_{\mathrm{c}}=0.15 \mathrm{l} \mathrm{kg}^{-1}\right)$ of FLU in gilthead sea bream is also smaller compared than that in sea bass (0.63 $\mathrm{l} \mathrm{kg}^{-1}$ : Rigos et al. 2002), indicating a low distribution of FLU from the blood to the tissue compartments of gilthead sea bream.

The total clearance of the drug $\left(\mathrm{CL}_{\mathrm{T}}\right)$ in gilthead sea bream is identical to that reported for Atlantic halibut (0.05 $\mathrm{l} \mathrm{kg}^{-1} \mathrm{~h}^{-1}$ : Samuelsen \& Ervik 1997). A lower $\mathrm{CL}_{\mathrm{T}}$ has been calculated for channel catfish $\left(0.0149 \mathrm{l} \mathrm{kg}^{-1}\right.$ $\mathrm{h}^{-1}$ : Plakas et al. 2000). In contrast, higher values of $\mathrm{CL}_{\mathrm{T}}$ have been reported for sea bass $\left(0.156 \mathrm{l} \mathrm{kg}^{-1} \mathrm{~h}^{-1}\right.$ : Rigos et al. 2002).

Following oral administration $\left(20 \mathrm{mg} \mathrm{kg}^{-1}\right)$ of FLU to gilthead sea bream, the maximum plasma concentration was relatively low $\left(1.73 \mu \mathrm{g} \mathrm{ml}^{-1}\right)$. In comparison, the maximum plasma concentration $\left(C_{\max }\right)$ of FLU was $3.1 \mu \mathrm{g} \mathrm{ml}^{-1}$ at a dose of $5 \mathrm{mg} \mathrm{kg}^{-1}$ in channel catfish (Plakas et al. 2000), 1.4 to $2.7 \mu^{-1} \mathrm{ml}^{-1}$ at a dose of 10 to $25 \mathrm{mg} \mathrm{kg}^{-1}$ in Atlantic halibut (Samuelsen \& Ervik 1997, Hansen \& Horsberg 1999), 1.07 to $1.91 \mu \mathrm{g} \mathrm{ml}^{-1}$ at a dose of $5 \mathrm{mg} \mathrm{kg}^{-1}$ in rainbow trout (Sohlberg et al. $1990,1994), 1.42$ to $2.26 \mathrm{\mu g} \mathrm{ml}^{-1}$ at a dose of 25 to $50 \mathrm{mg} \mathrm{kg}^{-1}$ in Atlantic salmon (Rogstad et al. 1993, Martinsen \& Horsberg 1995), and $1.9 \mu \mathrm{g} \mathrm{ml}^{-1}$ at a dose of $10 \mathrm{mg} \mathrm{kg}^{-1}$ in turbot (Hansen \& Horsberg 1999). The time of FLU to reach its maximum plasma concentration in gilthead sea bream $(16 \mathrm{~h})$ is within the values reported by the aforementioned studies (6 to $54 \mathrm{~h}$ ).

Based on the findings of Tsoumas et al. (1989), a bacterial pathogen is deemed as 'resistant', 'moderately susceptible' and 'susceptible' to oxolinic acid when its MIC is $>1.0,0.125$ to 0.5 and $<0.0625 \mu \mathrm{g} \mathrm{ml}^{-1}$, respectively. MICs reflect a quantitative laboratory measurement of bacterial sensitivity to tested drugs without providing a complete picture of the in vivo situation. In addition, combining drug tissue levels with MIC data to assess the clinical significance of drugs may complicate matters still further, since such drug concentrations are calculated by laboratory protocols and may not represent the biological activity of the drug in the target organism (Smith et al. 1994). However, a recent study demonstrated that it is valid to predict the treatment efficacy of oxytetracycline from in vitro data (Bruun et al. 2003). A rather theoretical assessment of a drug's efficacy against bacterial pathogens is the presumption that it is effective when its maximum plasma concentration following administration to the target species exceeds a factor of 4:1 (peak plasma level:MIC Stamm 1989). However, such assessment has been considerably criticised (Smith et al. 1994) and should be treated with caution.

According to guidelines of Tsoumas et al. (1989), our MICs for FLU using water supplemented with $2 \% \mathrm{NaCl}$ (1.2 to $0.019 \mathrm{\mu g} \mathrm{ml}^{-1}$ ) indicate that only Vibrio alginolyticus is resistant to FLU (MIC $>1 \mathrm{\mu g} \mathrm{ml}^{-1}$ ), with Photobacterium damsela ssp. piscicida and $V$. fluvialis 
showing a moderate susceptibility ( 0.15 to $0.3 \mu \mathrm{g} \mathrm{ml}^{-1}$ ). The most sensitive bacteria to FLU were $V$. damsela $\left(\mathrm{MIC}=0.019 \mu \mathrm{g} \mathrm{ml}^{-1}\right.$ ) and $V$. anguillarum Serotype $1 \mathrm{~b}$ $\left(\mathrm{MIC}=0.15 \mu \mathrm{g} \mathrm{ml}^{-1}\right)$; the latter is the most pathogenic and commonly occurring bacterial pathogen in euryhaline fish farming. However, the addition of $10 \mathrm{mM} \mathrm{Ca}^{2+}$ and $55 \mathrm{mM} \mathrm{Mg}^{2+}$ to the medium (approximating Mediterranean salinity in these cations) had a dramatic effect on FLU activity, increasing its MIC 30 times for $V$. anguillarum, $V$. alginolyticus and $V$. fluvialis and 8 times for $V$. damsela. In addition, no inhibition of $P$. damsela ssp. piscicida growth occurred at the highest drug concentration used $\left(38.25 \mu \mathrm{g} \mathrm{ml}^{-1}\right)$ when these 2 cations were added. These findings were not unexpected, since previous studies have stressed the strong antagonism of several drugs by marine cations (Smith 1989, Lunestad \& Goksoyr 1990, Barnes et al. 1995, Pursell et al. 1995, Torkildsen et al. 2000). The mechanism by which marine cations influence the antibacterial activity of drugs it not well known. Some assumptions include the formation of complexes by chemical interactions, decreased permeability of the bacterial cell by neutralisation, or interaction with the medium itself (Torkildsen et al. 2000, Lunestad \& Samuelsen 2001). The relative importance of these factors for bacterial pathogens and antibacterial agents of interest requires further investigation. The location at which the inhibitory effect of the cations on the drug is induced has also not been documented. It is likely that inhibition takes place mainly during the absorption stage.

The maximum plasma concentration of FLU following oral administration to gilthead sea bream $(1.73 \mu \mathrm{g}$ $\mathrm{ml}^{-1}$ ) exceeds a factor of 10:1 (peak plasma level:MIC) for the MICs obtained for distilled water with added $2 \% \mathrm{NaCl}$ for Vibrio anguillarum Serotype $1 \mathrm{~b}, \mathrm{~V}$. damsela and $V$. fluvialis, being almost 6 times higher than the MIC for Photobacterium damsela ssp. piscicida. Stamm (1989) reported that the effect of FLU is uncertain only against $V$. alginolyticus. However, considering the MICs for the medium supplemented with cations, it can be concluded that FLU is not effective against any of the bacterial pathogens tested. Further investigation including challenge tests with these bacterial pathogens followed by FLU treatment is required to confirm these findings.

In conclusion, this study demonstrates an adequate kinetic profile of FLU in gilthead sea bream characterised by rapid distribution and elimination and low tissue penetration. The bioavailability of the drug is comparable with that for other farmed fishes. The reported MICs of FLU indicate that the presence of marine cations in the medium have a significant impact on the activity of the drug, rendering questionable its use against bacterial pathogens in Mediterranean fish farming.

\section{LITERATURE CITED}

Bakopoulos V, Adams A, Richards RH (1995) Some biochemical properties and antibiotic sensitivities of Pasteurella piscicida isolated in Greece in comparison with strains from Japan, France and Italy. J Fish Dis 18:1-7

Barnes AC, Hastings TS, Amyes SGB (1995) Aquaculture antibacterials are antagonized by seawater cations. J Fish Dis 18:463-465

Boon JH, Nouws JMF, van der Heijden MHT, Booms GHR, Degen M (1991) Disposition of flumequine in plasma of European eel (Anguilla anguilla) after a single intramascular injection. Aquaculture 99:213-223

Bruun MS, Madsen L, Dalsgaard I (2003) Efficiency of oxytetracycline treatment in rainbow trout experimentally infected with Flavobacterium psychrophilum strains having different in vitro antibiotic susceptibilities. Aquaculture 215:11-20

Drlica K, Coughlin S (1989) Inhibitors of DNA gyrase. Pharmacol Ther 44:107-122

Elema MO, Hoff KA, Kristensen H G (1994) Multiple-dose pharmacokinetic study of flumequine in Atlantic salmon (Salmo salar L.). Aquaculture 128:1-11

Elema MO, Hoff KA, Kristensen HG (1995) Bioavailability of flumequine after oral administration in Atlantic salmon (Salmo salar L.). Aquaculture 136:209-219

Hansen PK, Horsberg TE (1999) Single-dose pharmacokinetics of flumequine in halibut (Hippoglossus hippoglossus) and turbot (Scophthalmus maximus). J Vet Pharmacol Ther 22:122-129

Ledo A, Dopazo CP, Romalde JL, Toranzo AE, Barja JL (1987) Effectiveness of different chemotherapeutic agents for controlling bacterial fish diseases. Bull Eur Assoc Fish Pathol 7:20-22

Lunestad BT, Goksoyr J (1990) Reduction in the antibacterial effect of oxytetracycline in seawater by complex formation with magnesium and calcium. Dis Aquat Org 9:67-72

Lunestad BT, Samuelsen OB (2001) Effects of sea water on the activity of antimicrobial agents used in aquaculture; implications for MIC testing. Aquaculture 196:319-323

Martinsen B, Horsberg TE (1995) Comparative single-dose pharmacokinetics of four quinolones, oxolinic acid, flumequine, sarafloxacin and enrofloxacin in Atlantic salmon (Salmo salar) held in seawater at $10^{\circ} \mathrm{C}$. Antimicrob Agents Chemother 39:1059-1064

Martinsen B, Oppegaard H, Wichstrom R, Myhr E (1992) Temperature-dependent in vitro antimicrobial activity of four 4-quinolones and oxytetracycline against bacteria pathogenic to fish. Antimicrob Agents Chemother 36: 1738-1743

Mercedes A, Blanch AR (1994) A set of keys for biochemical identification of environmental Vibrio species. J Appl Bacteriol 76:79-85

O'Grady P, Moloney M, Smith PR (1988) Bath administration of the quinolone antibiotic flumequine to brown trout (Salmo trutta) and Atlantic salmon (Salmo salar). Dis Aquat Org 4:27-33

Plakas SM, El Said KR, Musser SM (2000) Pharmacokinetics, tissue distribution and metabolism of flumequine in channel catfish (Ictalurus punctatus). Aquaculture 187:1-14

Pursell L, Samuelsen OB, Smith P (1995) Reduction in the invitro activity of flumequine against Aeromonas salmonicida in the presence of the concentrations of $\mathrm{Mg}^{2+}$ and $\mathrm{Ca}^{2+}$ ions found in seawater. Aquaculture 135:245-255

Rigos G, Tyrpenou A, Nengas I, Alexis M (2002) A pharmacokinetic study of flumequine in sea bass, Dicentrarchus labrax L. J Fish Dis 25:101-105 
Ritschel WA (1986) Handbook of basic pharmacokinetic, including clinical applications, 3rd edn. Drug Intelligence Publications, Hamilton, IL

Rogstad A, Ellingsen OF, Syvertsen C (1993) Pharmacokinetics and bioavailability of flumequine and oxolinic acid after various routes of administration to Atlantic salmon in sea water. Aquaculture 110:207-220

Samuelsen OB, Ervik A (1997) Single dose pharmacokinetic study of flumequine after intravenous, intraperitoneal and oral administration to Atlantic halibut (Hippoglossus hippoglossus) held in seawater at $9^{\circ} \mathrm{C}$. Aquaculture 158: 215-227

Samuelsen OB, Lunestad BT (1996) Bath treatment, an alternative method for the administration of the quinolones flumequine and oxolinic acid to halibut Hippoglossus hippoglossus and in vitro antibacterial activity of the drugs against some Vibrio sp. Dis Aquat Org 27:13-18

Smith JT (1989) Interaction between 4-quinolone antibacterials and multivalent metal ions. J Chemother 4(Suppl): 134-135

Smith P, Hiney M, Samuelsen OB (1994) Bacterial resistance to antimicrobial agents used in fish farming; a critical evaluation on method and meaning. Annu Rev Fish Dis 4: $273-313$

Sohlberg S, Czerwinska K, Rasmussen K, Soli NE (1990) Plasma concentrations of flumequine after intraarterial and oral administration to rainbow trout (Salmo gairdneri)

Editorial responsibility: David Bruno,

Aberdeen, Scotland, UK exposed to low water temperatures. Aquaculture 84 $355-361$

Sohlberg S, Aulie A, Soli NE (1994) Temperature-dependent absorption and elimination of flumequine in rainbow trout (Oncorhynchus mykiss Walbaum) in fresh water. Aquaculture 119:1-10

Stamm JM (1989) In vitro resistance by fish pathogens to aquacultural antibacterials, including the quinolones difloxacin (A-56619) and sarafloxacin (A-56620). J Aquat Anim Health 1:135-141

Stegeman JJ (1989) Cytochrome P-450 forms in fish: catalytic, immmunological and sequence similarities. Xenobiotica 19:1093-1110

Torkildsen L, Samuelsen OB, Lunestad BT, Bergh O (2000) Minimum inhibitory concentrations of chloramphenicol, florfenicol, trimethoprim/sulfadiazine and flumequine in seawater of bacteria associated with scallops (Pecten maximus) larvae. Aquaculture 185:1-12

Tsoumas A, Alderman DJ, Rodgers CJ (1989) Aeromonas salmonicida: development of resistance to 4-quinolone antibacterials. J Fish Dis 12:493-507

van der Heijden MHT, Keukens HJ, van den Nieuwboer WHFX, Mengelers MJB, Boon JH (1994) Plasma disposition of flumequine in common carp (Cyprinus carpio L. 1758), African catfish (Clarias gariepinus Burchell, 1822) and European eel (Anguilla anguilla L., 1758) after a single peroral administration. Aquaculture 123:21-23

Submitted: April 10, 2002; Accepted: July 22, 2002 Proofs received from author(s): February 26, 2003 